\title{
Pengaruh Perencanaan Terhadap Peningkatan Nilai Akreditasi MTs Al-Amiriyyah Blokagung Tegalsari Banyuwangi
}

\author{
Ribut Suprapto ${ }^{1}$, Muhammad Balya Khajjan ${ }^{2}$ \\ e-mail: ributsuprapto9@gmail.com ${ }^{1}$, balyakhajjan29@gmail.com ${ }^{2}$ \\ Prodi Manajemen Pendidikan Islam \\ Institut Agama Islam Darussalam Blokagung Banyuwangi
}

\begin{abstract}
This researching is directed at 4 main points, namely: (1) Planning of Al-Amiriyyah Islamic junior high school Blokagung Tegalsari Banyuwangi 2018/2019; (2) Increasing the accreditation value of Al-Amiriyyah islamic junior high school Blokagung Tegalsari Banyuwangi 2018/2019; (3) indluence of planning on increasing the accreditation value of Al amiriyyah islamic junior hihg school Blokagung Tegalsari Banyuwangi 2018/2019; (4) How much influence does planning have on increasing the accreditation value of AlAmiriyyah islamic junior high school Blokagung Tegalsari Banyuwangi 2018/2019. This researching uses quantitative descriptive methods. Product moment analysis is used in the data validity test and to find the reliability of the data using the Alpha formula, while in the hypothesis test using the F test and T test. Then the data analysis uses a simple linear regression model. The population of the researching is 37 teachers of AlAmiriyyah islamic junior high school Tegalsari Banyuwangi, To measure variables, researchers uses questionnaires for planning and accreditation. After analyzing the data, it was found that the influence of planning on increasing the accreditation value of AlAmiriyyah islamic junior high school Blokagung Tegalsari Banyuwangi 2018/2019 is $78 \%$, the remaining $22 \%$ is influenced by another variables.
\end{abstract}

Keywords: Planning, Accreditation

\begin{abstract}
Abstrak
Penelitian ini diarahkan pada 4 hal pokok, yaitu: (1) Perencanaan MTs. Al-Amiriyyah Blokagung Tegalsari Banyuwangi Tahun Pembelajaran 2018/2019; (2) Peningkatan nilai akreditasi MTs. Al-Amiriyyah Blokagung Tegalsari Banyuwangi Tahun Pembelajaran 2018/2019; (3) Pengaruh perencanaan terhadap peningkatan nilai akreditasi MTs AlAmiriyyah Blokagung Tegalsari Banyuwangi Tahun Pembelajaran 2018/2019; (4) Seberapa besar pengaruh perencanaan terhadap peningkatan nilai akreditasi MTs. AlAmiriyyah Blokagung Tegalsari Banyuwangi Tahun Pembelajaran 2018/2019. Penelitian ini menggunakan metode deskriptif kuantitatif. Analisis Product moment digunakan pada uji validitas data dan untuk mencari reliabilitas data menggunakan rumus Alpha, sedangkan pada uji hipotesis menggunakan uji $F$ dan uji $T$. Kemudian analisis data menggunakan model regresi linier sederhana. Populasi penelitian ini adalah guru MTs Al-Amiriyyah Blokagung Tegalsari Banyuwangi yang berjumlah 37 orang. Untuk mengukur variabel, peneliti menggunakan kuesioner untuk perencanaan dan akreditasi. Setelah melakukan analisis data yang dikumpulkan, ditemukan bahwa Pengaruh perencanaan terhadap peningkatan nilai akreditasi MTs. Al-Amiriyyah Blokagung Tegalsari Banyuwangi Tahun Pelajaran 2018/2019 sebesar 78\%, sisanya 22\% dipengaruhi oleh variabel lain.
\end{abstract}

Kata Kunci : Perencanaan, Akreditasi

Pengaruh Perencanaan Terhadap Peningkatan Nilai Akreditasi MTs Al-

Amiriyyah Blokagung Tegalsari Banyuwangi

Ribut Suprapto, Muhammad Balya Khajjan 


\section{A. Pendahuluan}

\section{Latar Belakang}

Pendidikan sering diidentikkan dengan sekolah, guru mengajar dikelas atau satuan formal lainnya. Pendidikan merupakan media mencerdaskan kehidupan bangsa yang dapat membawa bangsa ini pada era aufklarung (pencerahan), tujuannya adalah untuk membangun tatanan bangsa yang memiliki nilai-nilai kepintaran, kepekaan, serta kepedulian terhadap kehidupan berbangsa dan bernegara. Menurut Sudarwan (2010: 2) dalam bukunya menyebutkan bahwa pendidikan adalah aktivitas semua potensi dasar manusia melalui interaksi antar manusia dewasa dengan yang belum dewasa. Pendidikan merupakan proses membimbing, melatih, dan memandu manusia terhindar atau keluar dari sifat kebodohan. Oleh karena itu pendidikan sebagai aktifitas yang sadar akan tujuan, ia menempati posisi dan memposisikan manusia dalam kehidupan secara tepat.

Perencanaan pada dasarnya adalah sebuah usaha yang dilakukan secara terus menrus serta di aplikasikan dalam sebuah organisai untuk memilih langkah yang terbaik dari beberapa alternatif yang ada untuk mencapai sebuah tujuan yang telah di tentukan. Dalam konteks pendidikan di Indonesia pemerintah telah memberikan rambu-rambu, bagaimana menciptakan sekolah/madrasah yang memiliki kualitas baik, sesuai dengan Peraturan pemerintah Nomor 19 Tahun 2005 tentang Standar Nasional Pendidikan (SNP) perlunya disusun dan dilaksanakannya delapan standar nasional pendidikan, dan salah satu dari delapa standar nasional tersebut adalah standar isi.

Menurut Peraturan Menteri Pendidikan Nasional Nomor 22 Tahun 2006 tentang Standar isi bertuliskan bahwa standar isi mencakup materi dan tingkat kompetensi untuk mencapai kompetensi lulusan pada jenjang dan jenis pendidikan tertentu. Dalam upaya untuk mewujudkan tujuan pendidikan nasional telah ditetapkan standar kompetensi lulusan yang merupakan kriteria mengenai kualifikasi kemampuan lulusan, untuk mencapai kompetensi lulusan ditetapkan standar isi yang merupakan 
kriteria mengenai ruang lingkup materi dan tingkat kompetensi peserta didik untuk mencapai kompetensi lulusan pada jenjang dan jenis pendidikan tertentu.

Dalam Keputusan Menteri Pendidikan Nasional Nomor 087/U/2002 menyatakan Akreditasi sekolah adalah sebuah kegiatan penilaian kelayakan dan kinerja suatu sekolah berdasarkan kriteria (standar) yang dilakukan oleh badan akreditasi sekolah yang hasilnya diwujudkan dalam bentuk pangakuan peringkat kelayakan. Akreditasi sekolah dapat dijadikan sebagai ukuran ketercapain mutu suatu sekolah karena akreditasi adalah salah satu instrument dari pemerintah untuk mengetahui kondisi mutu pendidikan baik pada tingkat kabupaten/kota, tingkat provinsi, maupun tingkat nasional. Negara mempunyai kewajiban dalam memberikan layanan pendidikan yang bermutu kepada setiap warga negara melalui penyelenggaraan pendidikan pada satuan pendidikan. Pelaksanaan pendidikan melibatkan faktor internal maupun eksternal satuan pendidikan. Faktor internal meliputi kepala sekolah, guru, tenaga administrasi serta ketersediaan dan ketercukupan sarana dan prasarana pendidikan. Faktor eksternal mencakup dinas pendidikan dan masyarakat termasuk orang tua peserta didik.

Berdasarkan pengertian yang tertera di atas dapat disimpulkan bahwa akreditasi sekolah adalah sebuah usaha untuk menilai kelayakan setiap sekolah dengan membandingkan kenyataan yang ada dengan standar yang sudah ditetapkan. Alat ukur yang dipergunakan adalah 8 standar pendidikan nasional, meliputi: standar isi, standar proses, standar kompetensi lulusan, standar pendidikan dan tenaga kependidikan, standar sarana dan prasarana, standar pengelolaan, standar penilaian, dan standar pembiyaan. Apabila ditemukan kondisi sekolah memiliki standar yang sama dengan kriteria yang telah ditetapkan, maka sekolah itu terakreditasi. Sebaliknya, jika kemampuan sekolah dibawah standar yang telah ditetapkan, maka sekolah tidak terakreditasi. Akreditasi sekolah dilaksanakan mulai dari TK/RA, SD/MI, SMP/MTs, SMA/MA dan Perguruan Tinggi. Penilaian akreditasi akan mempengaruhi mutu sekolah 
dan tingkat kepercayaan masyarakat terhadap lembaga pendidikan. Semua lembaga layanan masyarakat diperlukan standarisasi agar masyarakat mengetahui secara transparan mutu layanan yang dilakukan oleh suatu lembaga pendidikan yang dibiayai dari anggaran negara dapat tercapai.

Sesuai dengan Undang-Undang Nomor 20 Tahun 2003 tentang Sistem Pendidikan Nasional pasal 5 bahwa masyarakat harus terlindung hak-haknya untuk mendapatkan layanan yang bermutu. Setiap lembaga pendidikan akan berusaha semaksimal mungkin untuk meningkatkan nilai akreditasinya. Salah satu lembaga pendidikan yang terus berupaya meningkatkan nilai akreditasi sekolah atau madrasah adalah MTs AlAmiriyyah Blokagung yang di percaya oleh sebagian wali murid sebagai wadah peserta didik berbasis pesantren yang memiliki akhlaqul karimah dan budi pekerti yang baik. Untuk melihat efektivitas strategi yang digunakan kepala sekolah MTs. Al-Amiriyyah Blokagung dalam meningkatkan nilai akreditasi lembaga, peneliti mencoba mengamati bagaimana pelaksanaan pelaksanaan strategi atau perencanaan yang diterapkan kepala sekolah MTs. Al-Amiriyyah Blokagung untuk mendapatkan nilai akreditasi A. Alasan peneliti memilih MTs. AlAmiriyyah Blokagung sebagai tempat penelitian pada tanggal 29 Juni 2019 dilatar belakangi oleh kemajuan yang signifikan pada MTs. AlAmiriyyah Blokagung terutama dari berbagai aspek. Perubahan ini terasa cukup nampak setelah terjadi seksesi kepemimpinan Kepala Sekolah MTs. Al-Amiriyyah Blokagung yaitu Bapak Masrofi S.Pd.I M.Pd.I dan sekarang telah diteruskan jabatannya oleh kepala sekolah MTs. Al-Amiriyyah yang baru yaitu Bapak Ahmadi M.Pd. I.

MTs. Al-Amiriyyah Blokagung adalah salah satu yayasan yang berada dalam naungan pondok pesantren Darussalam Blokagung. Sekolah/madrasah ini berlokasi di Dusun Blokagung, Desa Karangdoro, Kecamatan Tegalsari, Kabupaten Banyuwangi Provinsi Jawa Timur. Pada tahun 2015, MTs. Al-Amiriyyah Blokagung memperoleh nilai Akreditasi peringkat A (sangat baik). Dari yayasan atau lembaga sendiri mengharapkan MTs. Al-Amiriyyah agar mempertahankan nilai predikat A

Pengaruh Perencanaan Terhadap Peningkatan Nilai Akreditasi MTs Al-

Amiriyyah Blokagung Tegalsari Banyuwangi

Ribut Suprapto, Muhammad Balya Khajjan 
sebagai salah satu tujuan akhir supaya bisa menarik perhatian masyarakat luas dengan berbagai macam proses metode dan sistem yang digunakan MTs. Al-Amiriyyah agar bisa lebih baik dari sebelumnya meskipun telah terakreditasi A. Dengan kondisi demikian peneliti memiliki asumsi untuk meneliti tentang perencanaan peningkatan nilai akreditasi MTs. AlAmiriyyah Blokagung.

2. Rumusan Masalah

1) Bagaimana Perencanaan Pendidikan MTs. Al-Amiriyyah Blokagung Tegalsari Banyuwangi?

2) Bagaimana peningkatan nilai akreditasi MTs. Al-Amiriyyah Blokagung Tegalsari Banyuwangi?

3) Adakah pengaruh perencanaan terhadap peningkatan nilai akreditasi MTs. Al-Amiriyyah Blokagung Tegalsari Banyuwangi?

4) Seberapa besar pengaruh perencanaan terhadap peningkatan nilai akreditasi MTs. Al-Amiriyyah Blokagung Tegalsari Banyuwangi?

3. Tujuan Penelitian

1) Untuk mengetahui Bagaimana Perencanaan Pendidikan MTs. AlAmiriyyah Blokagung Tegalsari Banyuwangi.

2) Untuk mengetahui Bagaimana peningkatan nilai akreditasi MTs. AlAmiriyyah Blokagung Tegalsari Banyuwangi.

3) Untuk mengetahui apakah ada pengaruh perencanaan terhadap peningkatan nilai akreditasi MTs. Al-Amiriyyah Blokagung Tegalsari Banyuwangi.

4) Untuk mengetahui seberapa besar pengaruh perencanaan terhadap peningkatan nilai akreditasi MTs Al-Amiriyyah Blokagung Tegalsari Banyuwangi.

4. Manfaat Penelitian

a. Manfaat teoritis

Secara teoritis penelitian ini memberikan pengetahuan serta pengalaman baru bagi penulis dalam hal pelaksanaan dan penerapan ilmu pengetahuan dan dapat menjadi salah satu informasi bagi semua pihak terkait untuk melakukan penelitian selanjutnya yang 
berhubungan dengan pengaruh perencanaan terhadap peningkatan nilai akreditasi.

b. Manfaat praktis

Penelitian ini diharapkan dapat digunakan sebagai bahan masukan guna meningkatkan nilai akreditasi MTs Al-Amiriyyah Blokagung. Penelitian ini juga dapat digunakan untuk menambah pengetahuan dan pemahaman mengenai pengaruh perencanaan terhadap peningkatan nilai akreditasi serta real khususnya tentang akreditasi serta meningkatkan kemampuan yang dimiliki dalam mengamalkan Tri Dharma Perguruan Tinggi, Serta dapat menambah koleksi pustaka atau referensi untuk bahan bacaan dan kajian mahasiswa.

\section{Landasan Teori}

\section{Teori Perencanaan}

Perencanaan menurut Handoko dalam Ismaya (2015: 16) mengemukakan bahwa perencanaan merupakan pilihan atau sebuah pendapat penetapan tujuan organisasi dan penentuan strategi,dan juga standar yang sedang dibutuhkan guna untuk mencapai sebuah tujuan. Arti penting dari sebuah perencanaan terutama memberikan tentang kejelasan arah setiap perencanaan kegiatan. sehingga setiap poin kegiatan bisa diusahakan serta dilaksanakan secara efektif dan juga efesien. Muhammad Afandi dalam Saefullah (2014: 212) mengutip dari berbagai pendapat ahli tentang perencanaan, menguraikan bahwa perencanaan berkaitan dengan penetuan sesuatu hal yang dilakukan. Sebuah perencanaan juga mendahului pelaksanaan suatu kegiatan dikarenakan perencanaan merupakan suatu proses untuk menetukan arah dan juga mengidentifikasikan persyaratan yang akan diperlukan dengan berbagai cara yang paling efektif dan juga efisien. Berpangkal dari semua pemahaman yang sudah tertera diatas, perencanaan mengandung beberapa pokok pikiran, yaitu:

a. Melibatkan sebuah proses penetapan keadaan pada masa depan yang diinginkan. 
b. Suatu keadaan masa depan yang sedang diinginkan itu kemudian dibandingkan dengan sebuah keadaan sekarang sehingga sudah dapat dilihat dengan kesenjangannya.

c. Usaha guna untuk menutup kesenjangan juga dapat beragam dan juga merupakan alternatif yang mungkin bisa ditempuh.

d. milihan alternatif paling baik, dalam artian harus memiliki efektivitas dan efesiensi yang tinggi.

Menurut Udin dan Abin dalam Saefullah (2014: 233) ada beberapa unsur penting yang terkandung dalam perencanaan, yaitu:

a. penggunaan analisis yang bersifat rasional dan sistematis dalam perencanaan. Hal ini menyangkut dalam metode dalam perencanaan. Perencanaan pendidikan saat ini telah berkembang dengan berbagai penedekatan dan metodoliginya yang cukup kompleks dan rumit, seperti: model pendekatan social demend, man power strategic, dan comprehensive.

b. Proses pengembangan pendidikan dan pembangunan, yaitu sebuah perencanaan pendidikan bisa dilakukan dalam rangka reformasi pendidikan, yaitu sebuah proses menuju perkembangan pendidikan yang sedang dicita-citakan.

c. Prinsip efektivitas dan efesiensi, yaitu sebuah perencanaan pendidikan dengan pemikiran secara ekonomis yang sangat menonjol. seperti halnya penggalian sumber pembiayaan pendidikan, alokasi biaya, dan hubungan pendidikan dengan tenaga kerja.

d. Kebutuhan dan tujuan peserta didik dan masyarakat, artinya perencanaan pendidikan mencakup aspek internal dan eksternal dari keorganisasian sistem pendidikan.

e. Masalah strategi penanganan policy (kebijakan) secara operasional yang mewarnai dalam sebuah proses pelaksanaan perencanaan.

2. Prinsip-prinsip Perencanaan

Menurut Saefullah (2014: 237) Prinsip adalah pedoman dasar yang dijadikan sebagai kepribadian atau karakteristik sesuatu. Dalam hal ini, perencanaan pendidikan memiliki berbagai prinsip yang harus dijadikan 
tolok ukur. Tujuannya adalah agar perencanaan terlaksana sesuai dengan desain dan mekanisme yang sudah direncanakan. Oleh karena itu agar dapat mencapai sebuah tujuan dan menghasilkan rencana yang efektif dan efesien, perlu diperhatikan prinsip-prinsip perencanaan sebagai berikut:

a. Perencanaan hendaknya mempunyai dasar nilai yang jelas dan mantap. Nilai yang menjadi dasar biasanya berupa nilai budaya, nilai moral, nilai religious, ataupun gabungan ketiganya. Acuan yang jelas dan mantap akan memberikan motivasi yang kuat untuk menghasilkan rencana sebaik-baiknya.

b. Perencanaan hendaknya berangkat dari tujuan umum. Tujuan umum itu diperinci menjadi khusus. Apabila masih bisa diperinci menjadi tujuan khusus, tujuan khusus tersebut diperinci menjadi lebih terperinci lagi untuk memperoleh tingkat relevansi tinggi dengan tujuan yang akan dicapai.

c. Perencanaan hendaknya realistis. Perencanaan harus disesuaikan dengan sumber daya dan dana yang tersedia. Dalam hal sumber daya, baik kualitas maupun kuantitas manusia harus dipertimbangkan. Perencanaan sebaiknya tidak mengacu pada sumber daya yang diperkirakan dapat disediakan, akan tetapi mengacu pada sumber daya dan dana yang nyata.

d. Perencanaan hendaknya mempertimbangkan kondisi social budaya masyarakat, baik yang mendukung ataupun tidak. Kondisi social budaya tersebut misalnya: sistem nilai, adat istiadat, keyakinan, dan cita-cita. Bagi pendukung perencanaan tersebut hendaknya memanfaatkan secara maksimal faktor pendukung yang ada, adapun bagi penghambat hendaknya merencanakan cara ataupun solusi sebagai pengantisipasi.

e. Perencanaan hendaknya fleksibel. Meskipun berbagai hal sudah dipertimbangkan dalam proses pelaksanaanya dan masih terjadi hal-hal yang muncul diluar dugaan, maka hendaknya disedikan ruang gerak sebagai antisipasi masalah tersebut. 
3. Tujuan Perencanaan

Tujuan adalah target yang akan dcapai, Masa yang akan datang tidak dapat di deskripsikan secara pasti, oleh karena itu perencanaan yang terancang dan terurus dengan baik dengan mempertimbangkan apa yang telah tercapai, menganalisis dan membaca apa yang saat ini terjadi dan berusaha untuk mencapai target yang sudah di rencanakan menjadi alat perubah untuk mencapai target/kepastian yang tinggi dengan resiko yang minimal. Adapun tujuan perencanaan yaitu:

a. Mendukung koordinasi antar pelaku sekolah.

b. Menjamin agar perubahan/tujuan pendidikan yang telah ditetapkan dapat tercapai dengan tingkat kepastian yang tinggi dan resiko yang minimal.

c. Mengoptimalkan partisipasi warga sekolah dan masyarakat.

d. Menjamin tercapainya pengguna sumber daya secara berkeadilan, efektif, dan efisien.

4. Langkah-langkah perencanaan

Menurut Husaini Usman (2008: 23) langkah-langkah perencanaan ada empat. Yaitu:

a. Menetapkan sasaran atau tujuan

Langkah ini berkaitan dengan kebutuhan organisasi dan tujuan yang hendak dicapai. Dalam penentuan tujuan disusun pula prioritas utama dan sumber daya yang dimiliki sehingga memudahkan pelaksanaan rencana.

b. Menentukan keadaan situasi, dan kondisi saat ini

Situasi sekarang perlu diperhatikan sebelum perencanaan dibuat, kemudian diukur menurut kemampuan organisasi dari seluruh komponen yang ada secara sistematik.

c. Mengidentifikasi faktor kemudahan dan hambatan

Memperkuat faktor yang mendukung terlaksananya perencanaan dan meminimalisasi semua faktor yang akan menghambat. Demikian pula dengan antisipasi terhadap gangguan yang datang secara todak terduga.

Pengaruh Perencanaan Terhadap Peningkatan Nilai Akreditasi MTs Al- 
d. Mengembangkan rencana kegiatan untuk mencapai sebuah tujuan.

5. Jenis-jenis Perencanaan

Dengan melihat dan memperhatikan pengertian perencanaan yang telah di cantumkan sebelumnya, bahwa perencanaan merupakan langkah awal dalam penentuan tujuan yang akan di capai. Senada dengan apa yang di katan Saefullah (2014: 222-225) membagi beberapa jenis perencanaan yaitu:

a. Jenis Perencanaan Menurut Penggunaannya

1) Single use planning, yaitu perencanaan untuk satu kali pakai. Jika pelaksanaan telah selesai, perencaan tersebut tidak dipakai lagi.

2) Repeats planning, yaitu sebuah perencanaan yang digunakan untuk keperluan yang berulang-ulang sehingga bersifat permanen.

b. Jenis perencanaan menurut prosesnya

1) Policy planning, yaitu perencanaan yang berisi kebijakan tanpa dilengkapi dengan teknis pelaksanaannya secara sistematis.

2) Program planning, yaitu perencanaan yang merupakan penjelasan dan perincian dari Policy planning.

3) Operational planning, yaitu perencanaan yang memuat rencana mengenai bagaiman cara-cara melaksanakan pekerjaan tertentu agar lebih berhasil dalam pencapaian tujuan dengan daya guna yang lebih tinggi (efektif dan efisien).

c. Jenis perencanaan menurut jangka waktunya.

1) Long range planning, yaitu perencanaan jangka panjang yang membutuhkan waktu yang lama, biasanya memerlukan waktu lebih dari 10 tahun.

2) Intermediate planning, yaitu perencanaan jangka menengah. Sebuah perencanaan yang membutuhkan waktu "pemasangan" (gestation period). Perencanaan ini biasanya memerlukan waktu 5 tahun.

3) Short range planning, yaitu perencanaan jangka pendek. Sebuah perencanaan yang dipersiapkan dengan tergesa-gesa dan mendadak karena pentingnya dan waktu yang tersedia sangan sempit, perencanaan ini memerlukan waktu kurang dari 1 tahun.

Pengaruh Perencanaan Terhadap Peningkatan Nilai Akreditasi MTs Al- 
d. Jenis perencanaan menurut materinya.

1) personnel planning, yaitu perencanaan mengenai masalah kepegawaian. Dalam perencanaan ini, masalah pegawai ditinjau dan dibahas dari berbagai segi secara mendalam dan mendetail.

2) Financial planning, adalah perencanaan mengenai keuangan ataupun pemodalan (anggaran belanja) secara menyeluruh dan mendetail dari suatu kegiatan kerja sama untuk mencapai tujuan.

3) Industrial planning, yaitu perencanaan yang menyangkut kegiatan industri yang direncanakan sedemikian rupa agar terhindar dari hambatan dan rintangan dalam pencapaian tujuan.

4) Educational planning, yaitu perencanaan dalam kegiatan pendidikan misalnya: planning mengenai pendidikan SMK, SMA, dan lain-lain

e. Jenis perencanaan menurut segi umum dan khusus.

1) General plans (rencana umum), yaitu rencana yang dibuat garisgaris besarnya dan menyeluruh dari suatu kegiatan kerja sama.

2) Special Planning (rencana khusus), yaitu perencanaan mengenai masalah yang dibuat secara mendetail dan terperinci.

3) Overall Planning, yaitu perencanaan yang memberikan pola secara keseluruhan dari pekerjaan yang harus dilaksanakan. Dalam hal ini, perencanaan merupakan landasan dari fungsi-fungsi manajemen lainnya.

f. Jenis perencanaan menurut materinya.

1) personnel planning, yaitu perencanaan mengenai masalah kepegawaian. Dalam perencanaan ini, masalah pegawai ditinjau dan dibahas dari berbagai segi secara mendalam dan mendetail.

2) Financial planning, adalah perencanaan mengenai keuangan ataupun pemodalan (anggaran belanja) secara menyeluruh dan mendetail dari suatu kegiatan kerja sama untuk mencapai tujuan.

3) Industrial planning, yaitu perencanaan yang menyangkut kegiatan industri yang direncanakan sedemikian rupa agar terhindar dari hambatan dan rintangan dalam pencapaian tujuan. 
4) Educational planning, yaitu perencanaan dalam kegiatan pendidikan misalnya: planning mengenai pendidikan SMK, SMA, dan lain-lain

g. Jenis perencanaan menurut segi umum dan khusus.

1) General plans (rencana umum), yaitu rencana yang dibuat garisgaris besarnya dan menyeluruh dari suatu kegiatan kerja sama.

2) Special Planning (rencana khusus), yaitu perencanaan mengenai masalah yang dibuat secara mendetail dan terperinci.

3) Overall Planning, yaitu perencanaan yang memberikan pola secara keseluruhan dari pekerjaan yang harus dilaksanakan. Dalam hal ini, perencanaan merupakan landasan dari fungsi-fungsi manajemen lainnya.

6. Landasan Teori Tentang Akreditasi

Akreditasi sekolah adalah suatu kegiatan penilaian kelayakan dan kinerja suatu sekolah berdasarkan kriteria (standar) yang dilakukan badan akreditasi sekolah yang hasilnya diwujudkan dalam bentuk pangakuan peringkat kelayakan sebagaimana diatur dalam keputusan menteri pendidikan nasional nomor 087/U/2002. Akreditasi yaitu kegiatan penilaiyan kelayakan program dalam satuan pendidikan berdasarkan kriteria yang telah di tetapkan. Akreditasi sekolah merupakan kegiatan penilaian yang di lakukan oleh pemerintah atau lembaga mandiri yang berwenang untuk menentukan kelayakan program atau satuan pendidikan pada jalur pendidikan formal dan non formal pada setiap jenjang dan jenis pendidikan, berdasarkan kriteria yang telah di tetapkan, sebagai bentuk akuntabilitas publik yang di lakukan secara objektif, adil, transparan, dan komperhensif dengan menggunakan instrumen dan kriteria yang mengacu kepada Standar Nasional Pendidikan (SNP).

Menurut Permendikbud No. 59 tahun 2012, bahwa Akreditasi Nasional sekolah Madrasah (BAN-SM) meruapakan badan mandiri yang menetapkan kelayakan suatu program atau satuan pendidikan jenjang pendidikan dasar dan menengan jalur formal dengan mengacu

Pengaruh Perencanaan Terhadap Peningkatan Nilai Akreditasi MTs Al- 
Standar Nasional Pendidikan (SNP). Dari kedua pendapat di atas dapat disimpulkan bahwa Akreditasi sekolah adalah kegiatan penilaian yang dilakukan oleh pemerintah atau lembaga mandiri yang berwenang untuk menentukan kelayakan program dan satuan pendidikan pada jalur pendidikan formal dan non formal pada setiap jenjang dan jenis pendidikan. Berkaitan dengan pelaksanaan akreditasi, pemerintah telah menetapkan Badan Akreditasi Sekolah/Madrasah (BAN-S/M) sebagai badan evaluasi mandiri yang menetapkan kelayakan program dan/atau satuan pendidikan dasar dan menengahb jalur formal dengan mengacu pada standar nasional pendidikan. Dengan kebijakan ini di harapkan pelaksanaan akreditasi sekolah/madrasah dapat di lakukan secara objektif, adil, profesional, komprehensif, dan transparan sebagai bentuk akuntabilitas publik.

7. Tujuan Akreditasi

Adapun tujuan dari Akreditasi Sekolah sesuai dengan keputusan Menteri Pendidikan Nasional nomor: 087/U/2002 tahun 2002 adalah:

a. Untuk memperoleh gambaran kinerja sekolah yang dapat di pergunakan sebagai alat pembinaan, pengembangan, dan peningkatan mutu pendidikan sekolah/madrasah.

b. Untuk menentukan tingkat kelayakan suatu sekolah dalam penyelenggaraan pelayanan pendidikan sekolah/madrasah.

8. Fungsi Akreditasi

Sedangkan menurut Badan Akreditasi Nasional (2018: 9) fungsi dari Akreditasi Sekolah adalah sebagai berikutr:

a. Untuk pengetahuan, yaitu dalam rangka mengetahui bagaimana kelayakan dan kinerja sekolah di lihat dari berbagai unsur yang terkait yang mengacu pada kualitas yang di kembangkan berdasarkan indikator-indikator tertentu.

b. Untuk akuntabilitas, yaitu agar sekolah dapat mempertanggung jawabkan apakah layanan yang di berikan memenuhi harapan atau keinginan masyarakat.

Pengaruh Perencanaan Terhadap Peningkatan Nilai Akreditasi MTs Al- 
c. Untuk kepentingan pembangunan, yaitu agar sekolah dapat melakukan peningkatan kualitas atau pengembangan berdasrkan masukan dari hasil akreditasi.

9. Manfaat Akreditasi

Pelaksanaan Akreditasi sekolah/madrasah memiliki manfaat sebagai berikut:

a. Dapat di jadikan sebagai acuan dalam upaya peningkatan mutu Sekolah/Madrasah dan rencana pengembangan Sekolah/Madrasah.

b. Dapat di jadikan sebagai motivator agar Sekolah/Madrasah terus meningkatkan mutu pendidikan secara bertahap, terencana, kompetitif baik di tingkat kabupaten/kota, provinsi, nasional bahkan regional dan internasional.

c. Dapat di jadikan umpan balik dalam usaha pemberdayaan, dan pengembangan kinerja warga Sekolah/Madrasah dalam rangka menerapkan visi, misi, tujuan, sasaran, strategi, dan program Sekolah/Madrasah.

d. Membantu mengidentifikasi Sekolah/Madrasah dan program dalam rangka pemberian bantuan pemerintah, investasi, dana swasta dan donatur atau bentuk bantuan lainnya.

e. Bahan informasi bagi Sekolah/Madrasah sebagai masyarakat belajar untuk meningkatkan dukungan dari pemerintah, masyarakat, maupun sektor swasta dalam hal profesionalisme, moral, tenaga dan dana.

f. Membantu Sekolah/Madrasah dalam menentukan dan mempermudah kepindahan peserta didik dari satu sekolah ke sekolah lain, pertukaran guru, dan kerjasama yang saling menguntungkan.

10. Komponen-komponen Akreditasi

Menurut Surdika (2014: 8) dalam jurnalnya, komponenkomponen yang akan dievaluasi dalam akreditasi sekolah meliputi:

a. Standar isi 
Standar isi sebagaimana tercantum dalam peraturan pemerintah Nomor 19 Tahun 2005 yang secara keseluruhan mencakup (1) kerangka dasar dan struktur kurikulum yang merupakan pedoman dalam penyusunan kurikulum pada tingkatan satuan pendidikan. (2) beban belajar bagi peserta didik pada satuan pendidikan dasar dan menengah. (3) kurikulum tingkat satuan pendidikan yang akan dikembangkan oleh satuan pendidikan sesuai panduan penyusunan kurikulum sebagai bagian tidak terpisahkan dari standar isi. (4) kalender pendidikan untuk penyelenggaraan pendidikan pada satuan pendidikan jenjang pendidikan dasar dan menengah.

b. Standar proses

Standar proses adalah standar nasional pendidikan yang berkaitan dengan pelaksanaan pembelajaran pada satuan pendidikan untuk mencapai kompetensi lulusan.

c. Standar kompetensi lulusan

Standar kompetensi lulusan adalah standar yang digunakan untuk pedoman penilaian dalam penentuan kelulusan peserta didik dari satuan pendidikan. Sesuai dengan peraturan Menteri Pendidikan Nasional no. 23 tahun 2006 tentang standar kompetensi lulusan meliputi: (1) standar kompetensi lulusan satuan pendidikan. (2) satandar kompetensi kelompok mata pelajaran.

d. Standar pendidikan dan tenaga kependidikan

Standar pendidikan dan tenaga kependidikan meliputi tenaga kependidikan yang bertugas melaksanakan administrasi, pengolahan, pengembangan, pengawasan, dan pelayanan teknis untuk menunjang proses pendidikan pada satuan pendidikan (UU 20 Tahun 2003), dan pendidik merupakan tenaga profesional yang bertugas merencanakan dan melaksanakan proses pembelajaran, menilai hasil pembelajaran, melakukan pembimbingan, dan pelatihan, serta melakukan penelitian dan pengabdian kepada masyarakat.

Pengaruh Perencanaan Terhadap Peningkatan Nilai Akreditasi MTs Al- 
e. Standar sarana dan prasarana

Menurut Bafadal (2004: 2) mendefinisikan sarana dan prasarana adalah semua perangkat peralatan, bahan, dan perabot yang secara langsung digunakan dalam proses pendidikan disekolah. Meliputi: lahan, ruang kelas, perpustakaan, ruang pendidik dan tempat-tempat yang dibutuhkan dalam ruang lingkup sekolah.

f. Standar pengelolaan

Standar pengelolaan satuan pendidikan dilaksanakan berdasarkan standar pelayanan minimal dengan prinsip manajemen berbasis sekolah/madrasah.

g. Standar pembiayaan

Standar pembiayaan dalam peraturan pemerintah No. 69 Tahun 2009 meliputi biaya investasi, biaya operasi, dan biaya personal.

1) Biaya investasi satuan pendidikan meliputi biaya pengadaan sarana dan prasarana pendidikan, modal kerja tetap, dan pengembangan sumber daya manusia.

2) Biaya operasi satuan pendidikan mencakup gaji tenaga pendidik, peralatan pendidikan, biaya pemeliharaan saarana dan prasarana, pajak, asuransi, dan lain sebagainya.

3) Biaya personal mencakup biaya pendidikan yang harus dibayar peserta didik agar dapat mengikuti proses belajar.

h. Standar penilaian

Standar penilaian menurut peraturan pemerintah No. 20 Tahun 2007 di antaranya penilaian hasil belajar oleh pendidik, penilaian hasil belajar oleh satuan pendidikan, dan penilaian hasil belajar oleh pemerintah.

\section{E. Kajian Terdahulu}

Beberapa penelitian terdahulu yang berhubungan dengan penelitian ini dan di jadikan pembanding bagi penelitian ini adalah sebagai berikut: 
1. Penelitian Anang lubis, dengan judul "Perencanaan Pengembangan Sekolah (Studi Kasus Di SMPN 2 Paiton Probolinggo)" dengan metode kualitatif. Hasil dari penelitian ini yaitu perencanaan pengembangan di SMPN 2 Paiton Probolinggo disusun dalam dua bentuk variabel yaitu rencana strategis dan operasional. Perebedaannya adalah dalam metode yang digunakan.

2. Penelitian Diah Agustina, dengan judul "Pengaruh Program Akreditasi Terhadap Peningkatan Kualitas Pendidikan Di Kabupaten Malang. Metode yang digunakan adalah kuantitatif. Hasil dari penelitian ini menunjukkan bahwa adanya pengaruh yang signifikan terhadap peningkatan kualitas pendidikan di kabupaten Malang. Perbedaanya terdapat pada variabel yang digunakan.

\section{F. Metode penelitian}

1. Jenis penelitian menggunakan metode kuantitatif deskriptif.

2. Populasi yang digunakan dalam penelitian ini bersifat penelitian populsi, karena subjek kurang dari 100.

3. Teknik pengumpulan data peneltian ini adalah observasi, angket, dan dokumentasi.

4. Validitas data penelitian ini menggunakan korelasi product moment.

5. Reliabilitas data penelitian ini menggunakan rumus alpha.

6. Uji normalitas data penelitian ini menggunakan rumus kolmogrov smirnov.

7. Analisis data penelitian menggunakan rumus regresi linier sederhana.

\section{G. Hasil}

a) Uji Asumsi Klasik (Uji Normalitas Data )

Uji normalitas merupakan cara untuk menguji apakah variabelvariabel dalam sebuah model regresi mempunyai distribusi normal atau tidak. Pengujian dilakukan dengan mengunakan Kolmogorov Simirov yaitu dengan melihat bagaimana penyebaran. 
Tabel 1

Hasil Uji Normalitas

One-Sample Kolmogorov-Smirnov Test

\begin{tabular}{|ll|r|r|}
\hline & & Perencanaan & Akreditasi \\
\hline $\mathrm{N}$ & & 37 & 37 \\
Normal Parameters ${ }^{\mathrm{a}, \mathrm{b}}$ & Mean & 36.46 & 39.70 \\
& Std. Deviation & 5.247 & 4.977 \\
\cline { 2 - 4 } Most Extreme Differences & Absolute & .086 & .124 \\
& Positive & .086 & .124 \\
& Negative & -.077 & -.073 \\
\cline { 2 - 4 } Test Statistic & & .086 & .124 \\
Asymp. Sig. (2-tailed) & & $.200^{\mathrm{c}, \mathrm{d}}$ & $.165^{\mathrm{c}}$ \\
\hline
\end{tabular}

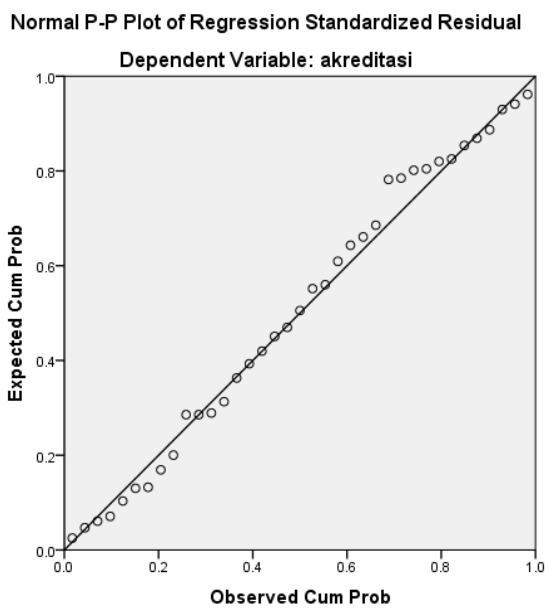

Sumber data: spss 23

Gambar 1 Sebaran Data Uji Normalitas

Dari plot di atas dapat disimpulkan bahwa:

1. Variabel-Variabel tersebut mempunyai hubungan yang cukup dekat, karena titik-titik pada diagram pencar itu terletak mendekat pada garis.

2. Variabel-variabel tersebut mempunyai hubungan positif karena titik-titik pada diagram pencar menunjukan gejala dari bawah ke kanan atas.

3. Variabel-variabel tersebut mempunyai korelasi yng linier, karena titiktitik pada diagram pencar menunjukkan gejala garis lurus.

Pengaruh Perencanaan Terhadap Peningkatan Nilai Akreditasi MTs Al-

Amiriyyah Blokagung Tegalsari Banyuwangi

Ribut Suprapto, Muhammad Balya Khajjan 
4. Sebaran data ada di sekitar garis diagonal sehingga dapat diambil kesimpulan bahwa data berdistribusi normal.

\section{b) Analisis Data dan Pengujian Hipotesis}

1) Analisis Data

Untuk mengetahui ada tidaknya pengaruh perencanaan terhadap peningkatan nilai akreditasi MTs. Al-Amiriyyah Blokagung peneliti menggunakan rumus regresi linier sederhana.

Adapun rumus sebagai berikut:

$\mathrm{Y}=\mathrm{a}+\mathrm{bX}$

Tabel 2

\section{Hasil regresi}

\begin{tabular}{|c|c|c|c|c|c|c|}
\hline \multirow{2}{*}{\multicolumn{2}{|c|}{ Model }} & \multicolumn{2}{|c|}{ Unstandardized Coefficients } & \multirow{2}{*}{$\begin{array}{c}\begin{array}{c}\text { Standardized } \\
\text { Coefficients }\end{array} \\
\text { Beta }\end{array}$} & \multirow[b]{2}{*}{$\mathrm{T}$} & \multirow[b]{2}{*}{ Sig. } \\
\hline & & B & Std. Error & & & \\
\hline \multirow[t]{2}{*}{1} & (Constant) & 9.170 & 2.772 & & 3.308 & .002 \\
\hline & Perencanaan & .837 & .075 & .883 & 11.124 & .000 \\
\hline
\end{tabular}

Sumber data: spss 23

Berdasarkan hasil yang tersaji pada tabel tersebut diperoleh regresinya yaitu:

$\mathrm{Y}=9,170+0,873 \mathrm{X}$

2) Pengujian Hipotesis

Analisis regresi memerlukan pengujian yang sesuai untuk memastikan keeratan hubungan dari variabel-variabel yang digunakan. Pengujian tersebut meliputi uji T dan F.

1. Uji T

Uji T digunakan untuk mengetahui apakah pengaruh variabel perencanaan $(\mathrm{X})$ dan variabel akreditasi (Y) signifikan atau tidak. Kesimpulan dari uji $\mathrm{T}$ diperoleh setelah membandingkan $\mathrm{t}$ hitung dan $\mathrm{t}$ tabel dengan taraf signifikansi 0,05 atau 5\%. Kriteria pengambilan keputusannya adalah:

Pengaruh Perencanaan Terhadap Peningkatan Nilai Akreditasi MTs Al-

Amiriyyah Blokagung Tegalsari Banyuwangi

Ribut Suprapto, Muhammad Balya Khajjan 
a) Apabila $\mathrm{t}$ hitung $>\mathrm{t}$ tabel, maka Ho ditolak dan Ha diterima, yang artinya variabel bebas secara parsial memiliki pengaruh nyata dan signifikan terhadap variabel terikat.

b) Apabila t hitung $<\mathrm{t}$ tabel, maka Ho diterima dan Ha ditolak, yang artinya variabel bebas secara parsial tidak memiliki pengaruh nyata dan tidak signifikan terhadap variabel terikat. Hasil analisis uji t dalam penelitian ini disajikan dalam tabel berikut:

\section{Tabel 3}

\section{Hasil Uji t}

\begin{tabular}{|c|c|c|c|c|c|}
\hline \multirow[b]{2}{*}{ Model } & \multicolumn{2}{|c|}{$\begin{array}{c}\text { Unstandardized } \\
\text { Coefficients }\end{array}$} & $\begin{array}{c}\text { Standardiz } \\
\text { ed } \\
\text { Coefficient } \\
\text { s }\end{array}$ & & \\
\hline & $\mathrm{B}$ & Std. Error & Beta & $\mathrm{T}$ & Sig. \\
\hline 1 (Constant) & 9.170 & 2.772 & & 3.308 & .002 \\
\hline Perencanaan & .837 & .075 & .883 & 11.124 & .000 \\
\hline
\end{tabular}

Sumber data: spss 23

Berdasarkan tabel hasil analisis uji $\mathrm{t}$ tersebut dapat ditarik kesimpulan bahwa pada variabel perencanaan $(\mathrm{X}) \mathrm{t}$ hitung $>\mathrm{t}$ tabel, yaitu 11, 124> 2,772, maka Ho ditolak dan Ha diterima. Hal tersebut dapat disimpulkan bahwa variabel perencanaan (X) mempunyai pengaruh yang signifikan terhadap peningkatan nilai akreditasi (Y).

2. Uji F

Uji $F$ atau uji koefisien regresi secara serentak digunakan untuk mengetahui apakah variabel perencanaan $(\mathrm{X})$ dan variabel peningkatan nilai akreditasi (Y) secara signifikan atau tidak. Kesimpulan dari uji $\mathrm{F}$ ini diperoleh dengan cara membandingkan antara $\mathrm{F}$ hitung dan $\mathrm{F}$ tabel dengan taraf signifikansi 0,05. Kriteria pengambilan keputusannya adalah:

Pengaruh Perencanaan Terhadap Peningkatan Nilai Akreditasi MTs Al- 
1) Apabila $\mathrm{F}$ hitung $>\mathrm{F}$ tabel, maka Ho ditolak dan Ha diterima, yang artinya variabel bebas secara simultan memiliki pengaruh yang signifikan terhadap variabel terikat.

2) Apabila $F$ hitung < F tabel, maka Ho diterima dan Ha ditolak, yang artinya variabel bebas secara simultan tidak memiliki pengaruh yang signifikan terhadap variabel terikat.

Hasil analisis uji $\mathrm{F}$ dalam penelitian ini disajikan dalam tabel berikut ini:

Tabel 4

\section{Hasil Uji F}

ANOVA $^{a}$

\begin{tabular}{|ll|r|r|r|r|r|}
\hline \multicolumn{1}{|l|}{ Model } & Sum of Squares & Df & Mean Square & F & Sig. \\
\hline 1 & Regression & 695.114 & 1 & 695.114 & 123.739 & $.000^{\mathrm{b}}$ \\
& Residual & 196.615 & 35 & 5.618 & & \\
\cline { 2 - 6 } & Total & 891.730 & 36 & & & \\
\hline
\end{tabular}

Sumber data: SPSS 23

Berdasarkan hasil yang tersaji pada tabel di atas diketahui bahwa $\mathrm{F}$ hitung > F tabel $(123,739>1,99)$ sehingga Ho ditolak dan Ha diterima, yang berarti variabel bebas, yaitu perencanaan $(\mathrm{X})$ dan peningkatan nilai akreditasi (Y) secara simultan atau bersama-sama memiliki pengaruh signifikan terhadap peningkatan nilai akreditasi (Y).

Sedangkan untuk mengetahui tentang besarnya pengaruh dari seluruh variabel independen (X) terhadap variabel dependen (Y) menggunakan out put regresi model summary berikut ini:

Tabel 5

Model Summary

Model Summary ${ }^{\text {b }}$

\begin{tabular}{|c|c|c|c|c|c|c|c|c|c|c|}
\hline & & & Adjuste & $\begin{array}{c}\text { Std. } \\
\text { Error of }\end{array}$ & & Chang & Statis & & & $\begin{array}{c}\text { Durbin } \\
- \\
\text { Watso } \\
\text { n }\end{array}$ \\
\hline Model & $\mathrm{R}$ & $\begin{array}{c}\mathrm{R} \\
\text { Square }\end{array}$ & $\begin{array}{c}\mathrm{d} \mathrm{R} \\
\text { Square }\end{array}$ & $\begin{array}{c}\text { the } \\
\text { Estimate }\end{array}$ & $\begin{array}{c}\text { R Square } \\
\text { Change }\end{array}$ & $\begin{array}{c}\mathrm{F} \\
\text { Change }\end{array}$ & df1 & df2 & $\begin{array}{c}\text { Sig. F } \\
\text { Change }\end{array}$ & \\
\hline
\end{tabular}




\begin{tabular}{|l|l|l|l|l|l|l|l|l|l|l|}
\hline 1 & $.883^{\mathrm{a}}$ & .780 & .773 & 2.370 & .780 & 123.739 & 1 & 35 & .000 & 1.580 \\
\hline
\end{tabular}

Sumber data: spss 23

Berdasarkan hasil yang disajikan pada tabel di atas diketahui bahwa nilai $\mathrm{R}$ atau koefisien korelasi sebesar 0,883, sedangkan R Square, hasil pengkaudratan nilai $\mathrm{R}$ atau koefisien determinasi (KD) sebesar 0,780, yang diartikan bahwa variabel bebas $\mathrm{X}$ memiliki pengaruh kontribusi sebesar 78,\% terhadap variabel $\mathrm{Y}$ dan $22 \%$ dipengaruhi oleh faktor-faktor lain diluar variabel $\mathrm{X}$.

\section{H. Pembahasan}

\section{Perencanaan $(\mathrm{X})$}

Sesuai dengan apa yang diuraikan pada bagian sebelumnya bahwa permasalahan pertama yang dipertanyakan dalam penelitian ini adalah bagaimana perencanaan MTs. Al Amiriyyah Blokagung Tegalsari Banyuwangi Tahun Pembelajaran 2018/2019, Hasil penelitian ini menunjukkan bahwa tingkat prosentase variabel $\mathrm{X}$ yang berhasil dicapai adalah sebagai berikut:

$$
\begin{aligned}
\% & =\frac{n}{N} \times 100 \\
& =\frac{1460}{1850} \times 100 \% \\
& =0,789=79 \%
\end{aligned}
$$

Berdasarkan data di atas, tingkat prosentase variabel $\mathrm{X}$ yang berhasil dicapai adalah sebesar 79\%. Jika dilihat pada tabel indeks konfirmasi nilai angket, maka nilai tersebut berada pada interval $61 \%$ sampai dengan $80 \%$ dengan kategori kuat. Dengan demikian menunjukkan bahwa perencanaan di MTs. Al Amiriyyah Blokagung Tegalsari Banyuwangi Tahun Pembelajaran 2018/2019 tergolong baik.

\section{Peningkatan Nilai Akreditasi (Y)}

Sesuai dengan apa yang diuraikan pada bagian sebelumnya, bahwa permasalahan kedua yang dipertanyakan dalam penelitian ini adalah bagaimana peningkatan nilai akreditasi di MTs. Al Amiriyyah Blokagung 
Tegalsari Banyuwangi Tahun Pembelajaran 2018/2019, Hasil penelitian ini menunjukkan bahwa tingkat prosentase variabel $\mathrm{Y}$ yang berhasil dicapai adalah sebagai berikut:

$$
\begin{aligned}
\% & =\frac{n}{N} \times 100 \\
& =\frac{1349}{1850} \times 100 \% \\
& =0,729=73 \%
\end{aligned}
$$

Berdasarkan data di atas, tingkat prosentase variabel $\mathrm{X}$ yang berhasil dicapai adalah sebesar $73 \%$. Jika dilihat pada tabel indeks konfirmasi nilai angket, maka nilai tersebut berada pada interval 61\% sampai dengan $80 \%$ dengan kategori kuat. Dengan demikian menunjukkan bahwa peningkatan nilai akreditasi di MTs. Al Amiriyyah Blokagung Tegalsari Banyuwangi Tahun Pembelajaran 2018/2019 tergolong baik.

3. Pengaruh perencanaan (X) terhadap peningkatan nilai akreditasi (Y)

Permasalahan ketiga yang ingin dijawab dalam penelitian ini adalah pengaruh variabel perencanaan $(\mathrm{X})$ terhadap peningkatan nilai akreditasi (Y). Berdasarkan hasil uji f diperoleh hasil bahwa f hitung yaitu 123,739 dibandingkan dengan $\mathrm{f}$ tabel dengan $\mathrm{N}=37$ taraf signifikansi 5\%=1,99, menghasilkan hasil uji f > dari f tabel maka Ha diterima. Dengan demikian hasil penelitian ini menunjukan bahwa ada pengaruh antara variabel $\mathrm{X}$ dan variabel Y,

4. Seberapa besar pengaruh perencanaan (X) terhadap peningkatan nilai akreditasi (Y)

Permasalahan keempat yang ingin dijawab dalam penelitian ini adalah pengaruh variabel perencanaan $(\mathrm{X})$ terhadap peningkatan nilai akreditasi (Y). Hasil penelitian menunjukan bahwa pengaruh perencanaan (X) mempunyai pengaruh yang signifikan terhadap nilai peningkatan nilai akreditasi MTs. Al-Amiriyyah sebesar 78\%, sisanya 22\% dipengaruhi oleh variabel lain 


\section{Kesimpulan}

Berdasarkan hasil penelitian dan analisis data sebagaimana diuraikan pada bab sebelumnya dapat disimpulkan sebagai berikut:

1. Berdasarkan hasil angket variabel perencanaan (X) di MTs. Al Amiriyyah Blokagung Tegalsari Banyuwangi Tahun Pembelajaran 2018/2019 diperoleh hasil hitung sebesar $79 \%$ yang termasuk kategori baik.

2. Berdasarkan hasil angket variabel peningkatan nilai akreditasi (Y) di MTs. Al Amiriyyah Blokagung Tegalsari Banyuwangi Tahun Pembelajaran 2018/2019 memperoleh hasil sebesar 73\% tergolong baik.

3. Berdasarkan hasil uji f diperoleh bahwa f hitung yaitu 123,739 dibandingkan dengan $\mathrm{t}$ tabel dengan $\mathrm{N}=37$ dengan taraf signifikansi $5 \%=1,99$, menghasilkan hasil uji f > dari f tabel maka Ha diterima. Dengan demikian hasil penelitian ini juga menunjukkan bahwa adanya pengaruh antara perencanaan terhadap peningkatan nilai akreditasi MTs. Al-Amiriyyah Blokagung Tegalsari Banyuwangi Tahun Pembelajaran $2018 / 2019$.

4. Berdasarkan perhitungan yang dilakukan dengan menggunakan rumus regresi linier sederhana $t$ hitung diperoleh 11,124 > 2,772 dengan taraf sigifikan $0,000<0,05$ yang berarti diperoleh pengaruh yang signifikan dengan koefisien regresi sebesar 0,555 yang dipersenkan menjadi 55,5\%. Dengan demikian besarnya pengaruh antara perencanaan terhadap peningkatan nilai akreditasi adalah sebesar $78 \%$ sedangkan $22 \%$ dipengaruhi oleh faktor lain.

\section{J. Daftar Pustaka}

Arikunto. 2002. Prosedur penelitian suatu pendekatan praktek. Jakarta: PT Rineka Cipta.

Awaludin, Aulia, Ar Rakhman. 2017. Akreditasi Sekolah Sebagai Suatu Upaya Penjaminan Mutu Pendidikan Di Indonesia. Universitas Indraprasta PGRI: hal 14-16

Budi, S.S. Yuliana, L. Hadi, Y. Y. 2018. Capaian Standar Nasional Pendidikan Sebagai Prediktor Mutu Sekolah, Pendidikan Dan Kebudayaan, Volume (3 Nomor 2): 130 
Djumingin S.S. 2016. Perencanaan Pembelajaran Bahasa, Sastra Indonesia dan Daerah. Makassar: BP UIN Makassar

Husaini Usman. 2008. Manajemen Teori, Praktek dan Riset Pendidikan. Jakarta: Bumi Aksara

Mahmud Hilal. 2015. Administrasi Pendidikan (Menuju Sekolah Efektif), Makassar Sulawesi Selatan: Aksara Timur, hal 9

Muhid, Abdul. 2012. Analisi Statistika 5 Langkah Praktis Analisis Statistic Dengan SPSS For Windows. Sidoarjo. Zifatama Publishing

Putra Dauly Haidar, MA. 2004. Pendidikan Islam dalam Sistem Pendidikan Nasional di Indonesia, Jakarta: Kencana.

Saefullah. 2014. Manajemen Pendidikan Islam, Bandung: Pustaka Setia

Suardika, P. Marhaeni, A. Koyan, I.W. 2014. Analisis Kesiapan Pemenuhan Aspek-Aspek Akreditasi Sekolah Dasar Negeri Di Kecamatan Gerokdak Journal Program Pascasarjana Universitas Ganesha, (volume 4 Tahun 2014): 8-9.

Sudarwan Danim. 2010. Pengantar Kependidikan. Bandung: ALFABETA

Sugiyono. 2016. Metode Penelitian Kuantitatif, Kualitatif, dan $R \& D$ Cetakan ke-23. Bandung: ALFABETA

Uno, Hamzah B. 2009. Perencanaan Pembelajaran. Jakarta: PT Bumi Aksara 